\title{
Health domains and race in generic preference-based health-related quality of life instruments in the United States literature
}

\author{
Claudia Cristina de Aguiar Pereira* \\ Mari Palta* \\ John Mullahy ${ }^{\star \star \star}$
}

\begin{abstract}
Race differences in health have been extensively analyzed and documented in the literature, especially between African Americans or blacks and whites in the United States. Despite the vast literature in the area, the majority of studies that explore the relationship between race and health use outcomes such as selfrated health, mortality or morbidity, and disability, but very few use Health-Related Quality of Life (HRQoL) measures and their domains or dimensions. This narrative review aims to provide a better understanding of the relationship between race and health domains that are commonly used in preference-based HRQoL measures. We investigated the literature on race, physical health, mental health, pain and discomfort, cognition, neurologic spectrum domains, dexterity, ambulation, vitality and social functioning domains. We conducted a literature search and review using the key words race and the health domain of interest, using medical and social sciences databases, such as MEDLINE/Pubmed, Web of Science, and the Google Scholar portal.The majority of the studies identified in the literature show that African Americans or blacks in the United States tend to have lower scores than whites throughout a variety of health domains found in preference-based HRQoL measures. This review also emphasizes the scarcity of studies that investigate some health domains, such as social functioning, dexterity, vitality and neurologic spectrum domains, and therefore we identify the need for more studies focusing on race and measures that address such domains.
\end{abstract}

Keywords: Race. Quality of life. EQ-5D. SF-6D. HUI2. HUI3. QWB health domains.

\section{Introduction}

Race differences in health have been extensively analyzed and documented in the literature, especially between African Americans or blacks and whites in the United States (WILLIAMS, MOHAMMED, 2009; BARR, 2008; GASKIN; FRICK, 2008; SHAW et al., 2007; SCHULTZ; MULLINGS, 2006). Blacks usually have worse health than whites on an array of outcomes. For instance, in the year 2005, life expectancy at birth for blacks was 73.2 years, against 78.3 years for whites. Death rates are higher for blacks for all leading causes of death (NATIONAL CENTER FOR HEALTH STATISTICS, 2007).

\footnotetext{
* Post-doctorate at Johns Hopkins University, Bloomberg School of Public Health, Department of Population, Family and Reproductive Health.

${ }^{* *}$ Professor, University of Wisconsin - Madison, Department of Population Health Sciences, School of Medicine and Public Health.

${ }^{* * *}$ Professor, University of Wisconsin - Madison, Department of Population Health Sciences, School of Medicine and Public Health.
} 
Blacks also have higher rates of disease and disability than whites (WILLIAMS et al. 1997; WILLIAMS; MOHAMMED, 2009).

Despite the extensive literature in the area, the majority of the studies that explore the relationship between race and health use outcomes such as self-rated health, mortality or morbidity, and disability, but very few use health-related quality of life (HRQoL) measures and their domains. The concept of quality of life is distinct from health, although they are closely related. The terminology that describes quality of life can be rather heterogeneous. There are many conceptual differences in terms that have been historically used interchangeably, such as health status, functional status, quality of life and health-related quality of life (FAYERS; MACHIN, 2007).

HRQoL measures summarize health considering its multiple dimensions, by combining what are called domains or dimensions, such as physical health, mental health, social, role functioning, among others (PEREIRA, 2009; NAUGHTON; SHUMAKER, 2003; WARE; SHERBOURNE, 1992; WOLINSKY, 1988). Preference-based HRQoL measures form a special category of HRQoL measures. Measures of HRQoL can provide a quantifiable summary of an individual's health and well-being by bringing together factors, dimensions or domains that are thought to influence quality of life, such as physical, psychological, social, and functional aspects. Assessing levels of health on various domains is a key component of measuring population health (IBURG et al., 2001).

\section{Health domains}

Preference-based HRQoL summarizes multiple dimensions, domains or concepts of health using preference weights given to different health states. These weights are usually obtained from a sample of the general population using valuation techniques such as standard gamble or time trade-off (GOLD; STEVENSON; FRYBACK, 2002). Individuals in such samples are members of the general population who were asked to value a selection of health states from which a model is estimated to predict preferences for all the health states described by the measure. Among such measures are the EuroQol EQ-5D (EQ-5D), Health Utilities Index Mark 2 and Mark 3 (HUI2 and HUI3), Quality of Well-Being Scale (QWB-SA) and SF-6D, which is computed from the SF-36v2 ${ }^{\mathrm{TM}}$ or the SF-12v2 ${ }^{\mathrm{TM}}$ (FRYBACK et al., 2007a; FRYBACK et al., 2007b, SHAW et al., 2007; BRAZIER; ROBERTS; DEVERILL, 2002; BRAZIER; ROBERTS, 2004). These instruments differ somewhat in the health domains they consider and they produce different scores and disutilities (i.e. differences in mean utility between having and not having a health condition), so the assessments may differ depending on which one is chosen. Although these instruments aim at measuring a similar construct, there are important differences among them in how this is accomplished (COONS; SHAW, 2005), especially because they assess different health domains or health dimensions (Figure 1). These

FIGURE 1

Summary of domains within each HRQoL index

\begin{tabular}{|c|c|c|c|c|c|}
\hline \multirow{2}{*}{$\begin{array}{l}\text { Number of } \\
\text { Domains }\end{array}$} & SF6D-SF36v2 ${ }^{T M}$ & QWB-SA & $E Q-5 D$ & HUI2 & HUI3 \\
\hline & 6 & 4 & 5 & 6 & 8 \\
\hline \multirow{6}{*}{$\begin{array}{l}\text { Common or } \\
\text { Similar Domains }\end{array}$} & Physical Functioning & Physical Activity & - & - & - \\
\hline & & Mobility & Mobility & Mobility & Ambulation \\
\hline & Mental Health & - & Anxiety/Depression & Emotion & Emotion \\
\hline & - & - & - & Cognition & Cognition \\
\hline & Body Pain & - & Pain/Discomfort & Pain & Pain \\
\hline & & Self-care and usual activities & Self-care & Self-care & - \\
\hline \multirow{4}{*}{ Unique Domains } & Role Limitation & Acute and Chronic Symptoms & Usual Activities & Sensation & Vision \\
\hline & Social Functioning & - & - & - & Hearing \\
\hline & Vitality & - & - & - & Speech \\
\hline & & & & & Dexterity \\
\hline
\end{tabular}


measures have been increasingly used to document levels of population health and health disparities, so it becomes important to investigate the current literature on race and each of these health domains separately.

\section{Physical health, self-care, usual activities, role limitation, mobility and race}

Physical health entails physical functioning and how physical limitations affect the way daily activities are performed. Functioning is thought to be a relatively objective measure because self-reported information can be compared with other sources of data, such as direct observation and performance measures. Historically, the RAND Medical Outcomes Study (MOS) that generated the RAND-36 ${ }^{1}$ considered the functioning part of HRQoL to include basic activities such as self-care (e.g., dressing and bathing), and ability to work, including paid and unpaid labor (HAYS; HAHN; MARSHALL, 2002). Physical health is assessed in the instrument called SF6D in one of its health domains, called physical functioning. The SF-6D is derived from the SF-36V2 ${ }^{\text {TM }}$ items that inquire about limitations in vigorous or moderate activities and how much physical health limits work. Additionally, the SF-36v2 ${ }^{\mathrm{TM}}$ assesses role limitations caused by physical health problems (4 items). The QWB-SA instrument contains a set of items that assess physical activity limitation issues over the previous 3 days (yesterday, two days ago and three days ago).

For the most part, the evidence from the literature indicates that blacks have worse physical health than whites (THEIS et al., 2007; MAYS; COCHRAN; BARNES, 2007; PASKETT et al., 2008; BOWEN; GONZÁLEZ, 2008), which includes worse self-reported physical health status and also higher rates of several diseases, including chronic ones such as hypertension, diabetes, stroke, and arthritis. For instance, it has been found that when compared with whites, a higher proportion of blacks had arthritis-attributable activity limitations, work limitations, and severe joint pain (CDC, 2005). A study that was aimed at estimating the U.S. national prevalence of arthritis-attributable work limitation (AAWL) among individuals, ages 18-64 with doctor-diagnosed arthritis, identified that the multivariable-adjusted likelihood of AAWL was moderately higher among nonHispanic blacks than whites (THEIS et al., 2007). When looking at other sub-groups of this population, these differences could be even more pronounced. For example, among women who are breast cancer survivors, blacks reported worse physical functioning and general health compared with white survivors (PASKETT et al., 2008).

The ability to walk is central to daily life. Difficulty in walking can disrupt essential activities and lead to isolation and other problems. Lower extremity mobility problems often stem from common medical conditions, such as musculoskeletal factors, cardio-respiratory fitness, balance and vision (IEZZONI et al., 2001). The QWB-SA, the EQ-5D, and the Health Utility Index, Mark 2 and Mark 3, HUI2 and HUI3, respectively, have health domains called mobility or ambulation (Figure 1). There is evidence that blacks have worse mobility than whites. For instance, using data from the National Health Interview Survey Disability Supplement (NHIS-D), lezzoni and colleagues (IEZZONI et al., 2001) found that the estimated adjusted mobility problem rates were higher for blacks than for whites. Another study by Thorpe and colleagues (THORPE et al., 2009) examined the racial differences in probabilities of transitioning across three disability levels for walking half a mile in a community-dwelling population of older women and found that among high-functioning women, African Americans

\footnotetext{
1 The RAND 36-Item Health Survey 1.0 (distributed by RAND) includes the same items as those in the SF-36, but the recommended scoring algorithm is somewhat different from that of the SF-36 (HAYS; HAHN; MARSHALL, 2002).
} 
were more likely to be disabled at the next round of the survey than were their white counterparts. Additionally, black women who were initially pre-clinically disabled were more likely to die before the next round and after adjustments for age, education and perceived income inadequacy; if black women were pre-clinically disabled, they were at increased risk of becoming disabled in comparison to white women (THORPE et al., 2009).

Despite this evidence, it is still unclear whether older adults of different races or ethnicities vary in the ways they perceive functional limitations. Regardless of such potential variation, self report is clinically relevant, as many diagnoses (and subsequent care) depend on self-reported disability (SPENCER et al., 2008).

As it could be noted in several studies that assess black and white differences in physical health, physical functioning and disability, blacks have consistently fared worse than whites. Such findings are also consistent when considering sub-groups within racial categories.

\section{Dexterity and race}

The evidence on race differences in perceived functional limitations, including dexterity is still scarce (SPENCER et al., 2008). A study conducted by Spencer and colleagues examined self-reported hand function among people aged 70 and older in New York City and performance-based assessment of strength, using an instrument called hand dynamometer, and dexterity using the Moberg Pick-Up Test (SPENCER et al., 2008). Their results indicated that selfreported hand function was associated with weaker grip strength in African-American and Hispanic participants but not in white participants. Additionally, self-reported difficulty with hand function was associated with poorer dexterity in all three groups. They also observed similar results in a subsample of participants with arthritis. Their results suggest that culture or socio-environmental differences associated with culture may influence reports of this type of functional limitation.

\section{Mental health and race}

Mental health is often described as a state of successful performance of mental function that results in productive activities, fulfilling relationships with other individuals, and the ability to adapt to change and cope with adversity (DHHS, 2001). This definition refers to the ability of successfully navigating through different challenges encountered in life, like the capacity to address anxiety-provoking situations, deal with different daily hassles, relationship problems and other difficult problems in general. Good mental functioning is regarded as an important aspect of wellbeing (LaVEIST, 2005).

Most generic preference-based HRQoL instruments, such as the SF-6D, the EQ-5D, and the HUI2 and HUI3 have mental healthrelated domains. The SF-6D mental health domain derives from the SF-36v2 ${ }^{\mathrm{TM}}$ items about how much of the time individuals consider themselves to be very nervous and downhearted and depressed. The EQ-5D has an anxiety or depression domain, which assesses the self-reported level of anxiety or depression of the individual. Both the HUI2 and the HUI3 have a domain or attribute called emotion, which uses concepts such as being happy, free of worry, fretful, angry, irritable and angry.

Solid nationwide estimates for racial differences in the prevalence of mental disorders are not available. The estimates for the U.S. usually come from small studies or larger studies that are geographically limited. There is general consensus that the overall rate of mental illnesses among minorities is similar to that of the general population (LaVEIST, 2005). A study called National Comorbidity Survey (NCS), which was nationally representative of the U.S. population, provides some prevalence estimates (KESSLER et al., 1994; KESSLER et al., 1996). Among the findings is that African Americans were less likely than whites to suffer from major depression. However, rates of depression, anxiety disorders and phobia were higher among African American women than among African American men. A similar gender pattern was 
found for whites. The NCS results indicate that blacks had lower prevalence rates for the disorders the study assessed (KESSLER et al., 1996). ${ }^{2}$

Despite the aforementioned prevalence issues, there is also a large body of literature showing that black Americans have higher rates of psychological distress and depression than whites (SIMPSON et al., 2007), but that relationship becomes less strong, or inverse, when measures of socio-economic status are taken into account (BRATTER; ESCHBACH, 2005; KESSLER; NEIGHBORS, 1986). This purely socioeconomic interpretation became the most widely accepted position, starting in the 1970's, when several studies found that the initial higher levels of distress among blacks were attenuated when social class was taken into account. On the basis of that evidence, it became widely accepted that race is not an independent determinant of psychological distress, but rather served as proxy for socioeconomic status - SES (KESSLER; NEIGHBORS, 1986).

On the other hand, some authors have identified what is called a paradox in African American health, that is, rates of psychological distress are usually higher than corresponding rates among whites. However, rates of other mental disorders such as depression and anxiety are lower (MAYS et al., 2007). Some explanations to these findings have been laid out. One of them is related to racial discrimination and stress. According to this view, higher distress levels may reflect chronic activation of feelings such as anger and hyper-vigilance. The perceived discrimination that implies restricted access to social resources would result in social pain, which in turn may draw the body away from homeostasis, and possibly activate stress-related allostatic responses (MAYS et al., 2007).

Another issue related to mental health is the use of antidepressants, which indicates the presence of depression and other disorders. A study has shown that black respondents had a significantly lower use of antidepressants than whites among individuals with depressive and anxiety disorders in the previous year. Further, depression severity was significantly associated with higher antidepressant use for whites but not for blacks (GONZÁLEZ et al., 2008). There is mixed evidence about stigma and beliefs about mental health issues and treatment. Another study found that African-Americans are less likely than whites to find antidepressant medication acceptable (COOPER et al., 2003). Another study stated that whites had higher stigma than African Americans for all types of mental health treatment they were inquired about (GIVENS et al., 2007).

Insofar as sub-groups, African-American women occupy a disadvantaged position in American society, as they typically perceive themselves as being less valued than whites or males. Such perceived disadvantage influences how they see themselves but also shapes the responses and expectations of others toward them. It is well documented in the literature that neither African American men, with whom they share a racial identity, nor women of other racial or ethnic groups encounter similar struggles of having both race and gender-based threats combined to impact their mental well-being. Their gender and race status also impacts SES attainment. Black women have lower educational achievement than their white counterparts. Nonetheless, they have higher levels of schooling than black males, which have implications for their mental health, given that the female/male gap in education may affect the availability of eligible mates, relationships, family dynamics and marital stability (BROWN, 2003). Overall, being a black woman in the United States has implications for occupation, benefits received, income and poverty status and

\footnotetext{
2 It is important to mention that this study did not include individuals living in prisons, nursing homes or hospitals, which is a major limitation when estimating prevalence. Moreover, although this evidence suggests the lower prevalence rates for blacks than for whites for mental conditions, it is hard to diagnose certain mental disorders and these lower prevalence rates may reflect that fact (LaVEIST, 2005), and may also be related to lower access to medical care by blacks, therefore being less diagnosed.
} 
marriage. Furthermore, the relationship of age and mental health for black women may be tied to the stage in the life cycle. For instance, younger African American women tend to struggle with family relationships, child rearing, employment and economic viability while older African American women may have developed resilience and effective coping strategies to deal with the issues they faced when they were younger (BROWN, 2003).

Overall, despite lower estimated prevalence rates of mental health disorders for African Americans in comparison to whites, there is substantial evidence that blacks fare worse in mental health than whites.

\section{Pain, discomfort and race}

There are significant gaps in the literature about the pain experiences of persons of racial minorities (GREEN et al., 2003) and there is also growing interest in understanding the influence of race and ethnicity on the experience of pain (EDWARDS et al., 2001b; EDWARDS; FILLINGIM; KEEFE, 2001). Investigators have recently indicated that African Americans report greater levels of pain than whites for conditions such as glaucoma, AIDS, migraine headache, jaw pain, postoperative pain, myofascial pain, angina pectoris, joint pain, nonspecific daily pain and arthritis (EDWARDS et al., 2001). Interpreting such results can be challenging because of potential group differences in disease severity and also in how health care is delivered to these patients. Several studies suggest that physicians tend to prescribe less analgesic medication for African Americans than for whites (NAMPIAPARAMPIL; NAMPIAPARAMPIL; HARDEN, 2009; NG et al., 1996a; NG et al., 1996b; HEINS et al., 2006). Although such findings may be confounded with racial and ethnic variations in health professionals' management of pain, the evidence that African Americans report greater pain than whites seems to hold across different age groups and other sub-groups (EDWARDS et al., 2001; SIMPSON et al., 2007).

Research has also shown that there are differences between white and black pain patients in their use of specific pain coping strategies, which refers to the consequence of individuals' appraisals of events (CANO; MAYO; VENTIMIGLIA, 2006; LAZARUS; FOLKMAN, 1984). For example, in a small study of participants with chronic pain (CANO; MAYO; VENTIMIGLIA, 2006), African-Americans reported significantly more pain severity and reported using diverting attention, prayer and hoping pain-coping strategies than whites, which have been found to be positively correlated with poorer pain outcomes in the literature. However, after the authors controlled for education, the racial group difference in prayer and hoping was the only one that remained. The same research also found significant interactions between race and education and suggested that educational level should be included in analyses exploring racial group differences in pain (CANO; MAYO; VENTIMIGLIA, 2006). Indeed, in the pain field, lower levels of educational attainment have been associated with maladaptive pain beliefs and coping strategies (CANO; MAYO; VENTIMIGLIA, 2006; ROTH; GEISSER, 2002). Another study noted that compared with whites, blacks placed lower values on health states with pain or discomfort or gave greater weight to the pain domain in their valuations of health states (GASKIN; FRICK, 2008). As the authors of that study noted, their findings may suggest that blacks would have a greater willingness to use pain relievers and pain management, however the evidence in the literature shows the opposite, as minorities often receive inadequate pain treatment (GASKIN; FRICK, 2008).

Overall, little is known about what influences differences in pain-related quality of life and further investigation is needed to understand racial differences in pain (GREEN et al., 2003).

\section{Cognition and race}

Cognitive functioning refers to the brain's thinking processes (LaVEIST, 2005). Generic preference-based HRQoL instruments vary in what questions are asked to assess 
cognitive functioning. For example, the HUI2 assesses whether an individual has normal learning and remembering skills for a person of a that age; learns and remembers school work more slowly than classmates as judged by parents and/or teachers; learns and remembers school work very slowly and usually requires special education assistance (TORRANCE et al., 1996). The HUI3 has a different set of items and classification, asking questions related to remembering and forgetting and difficulty in trying to solve day to day problems (FEENY et al., 2002).

One of the ways to assess thinking processes is by inquiring about intelligence and learning, similarly to the approach of the HUI2. There is vast literature on intelligence test scores and a black-white group difference on these tests has been found throughout the literature for over 90 years (PESTA; POZNANSKI, 2008). Despite such differences, there is no consensus about its causes (STERNBERG; GRIGORENKO; KIDD, 2005). Nevertheless, the evidence at large points to socially rooted factors. For instance, blacks are less likely to attend college than whites, and the ones that do, on average, have lower standardized test scores, grade point averages (GPAs) and also higher dropout rates (PESTA; POZNANSKI, 2008).

On the other hand, a large number of studies about cognition and race deal with the elderly population, as they are the population sub-group that is most often affected by cognitive related disorders due to the aging process. For instance, a study about depression severity, age, race and cognitive domains showed that race had significant negative correlations with processing speed, language, executive function and working memory (SHELINE et al., 2006). Another study showed that older African Americans have lower cognition scores than older whites (SKARUPSKI et al., 2007).

Overall, whether cognition in HRQoL is viewed as intelligence and the learning related process or as the ability to remember or think and solve day to day problems, blacks seems to fare worse than whites in cognitive functioning.

\section{Neurologic spectrum domains (hearing, vision, speech and sensation) and race}

Hearing, vision, speech and sensation are domains related to neurologic functioning. Recent evidence suggests that race is a critical variable for outcomes in neurological disorders. Nevertheless, comprehensive studies of racial minorities in some neurogenic disorders such as communication related ones are still lacking (ELLIS, 2009).

Among the few examples found in the literature, there is a study about speech and communication, which found significantly lower verbal and non-verbal memory among non-demented elderly African Americans than among whites (MANLY et al., 1998).

With respect to hearing, a study that used cross-sectional data suggested that age related decline in audition among the elderly varies by race and gender. The same study also suggested that given the high prevalence of hearing problems in the aging population and the variation across groups, there is a need to understand the factors related with such differences, so as to improve prevention and develop appropriate interventions (PRATT et al., 2009).

\section{Other domains and race}

Some domains are exclusive to a specific generic HRQoL instrument. The vitality and the social functioning domains are examples of such. Following is a brief description of the literature regarding these domains and race.

\section{Vitality}

Vitality is a health domain found in the SF-6D, derived from SF-36v2 ${ }^{\mathrm{TM}}$ vitality item 2 (BRAZIER et al., 2002). Respondents are asked if they have a lot of energy, all of the time, most of the time, some of the time, little of the time, or none of the time. There are some studies that consider the vitality domain independently, mostly from administering the SF-36v2 ${ }^{\mathrm{TM}}$ to groups of the population with certain conditions, such as patients with diabetes mellitus type 2 and 
undergoing dialysis (BENNETT et al., 2008; UNRUH et al., 2006; LEE; CHABOYER; WALLIS, 2008). Among such studies, a few include race as a control variable. To the best of our knowledge, no studies have looked at this health domain in the general population, specifically focusing on racial differences.

\section{Social functioning}

Social functioning is another exclusive domain of the SF-36v2TM, SF-6D family of HRQoL instruments. In the SF-6D, this domain specifically addresses the extent to which respondents own health limits social activities, with 5 levels of responses: none of the time, a little of the time, some of the time, most of the time or all of the time (BRAZIER et al., 2002). Very little is known about this domain in relation to race in the general population. Similarly to the vitality domain, we have found no studies that analyze the relationship of the social functioning domain and race in the general population. Furthermore, there are very few studies that examine the relationship between race and this domain in sub-groups of the population. One example is a study that examined racial differences in the use of lumbar spine radiographs, using the SF-36 in the Veterans Health Study. Their results show that non-whites had significantly lower social functioning scores than whites (SELIM et al., 2001).

\section{Discussion and conclusion}

This study investigates the literature pertaining to race and preference-based HRQoL measures in the United States. Throughout our assessment of the literature,

\section{References}

BARR, D. A. Health disparities in the United States: social class, race, ethnicity, and health. First Edition. Baltimore: Johns Hopkins University Press, 2008.

BENNETT, W.; OUYANG, P.; WU, A.; BARONE, B.; STEWART, K. Fatness and fitness: how do they influence health-related we found that the majority of studies show that blacks have lower HRQoL than whites as captured by many domains. These results remain, when studies control for confounders and examine the racial difference for different sub-groups of the population.

Blacks in the United States have the lowest life span, with average estimated life expectancy in 2005, eight years lower than the national average (NATIONAL CENTER FOR HEALTH STATISTICS, 2007). They are also disproportionately burdened by diseases such as hypertension, diabetes, HIV/AIDS, heart disease, and violence as a public health problem (WARE; LIVINGSTON, 2004). We sought a different approach to document disparities by investigating health domains, and across the publications examined, the disparities between blacks and whites are confirmed in such health dimensions or domains.

This review also shows the need for additional studies addressing race and HRQoL, because for some domains, such as social functioning, dexterity, vitality and neurologic spectrum, it was difficult to find any literature in relation to race.

Furthermore, there is still the challenge for researchers in this field to ascertain how much of the differences is determined by objectively measurable differences in health and how much is due to differences in the way individuals report on their health relative to different norms and expectations (IBURG, 2001); this is of particular importance in the presence of discrimination, healthcare access disparities, coping and resilience faced by African Americans and those who have health issues in general.

quality of life in type 2 diabetes mellitus? Health and Quality of Life Outcomes, Hamilton, v. 6, n. 110, p. 1-7, 2008.

BOWEN, M.; GONZÁLEZ, H. Racial/ethnic differences in the relationship between the use of health care services and functional disability: the health and retirement study 
(1992-2004). Gerontologist, Fairfax, v. 48, n. 5, p. 659-67, 2008.

BRATTER, J.; ESCHBACH, K. Race/ethnic differences in nonspecific psychological distress: evidence from the National Health Interview Survey. Social Science Quarterly, Houston, v. 86, n. 3, p. 620-644, 2005.

BRAZIER, J.; ROBERTS, J.; DEVERILL, $M$. The estimation of a preference-based measure of health from the SF-36. Journal of Health Economics, v. 21, n. 2, p. 27192, 2002.

BRAZIER, J.; ROBERTS, J. The estimation of a preference-based measure of health from the SF-12. Medical Care, n. 42, p. 851-9, 2004.

BROWN, D. A conceptual model of mental well-being for African American women. In: BROWN, D.; KEITH, V. (Ed.). In and out of our right minds: the mental health of African American women. New York: Columbia University Press, 2003.

CANO, A.; MAYO, A.; VENTIMIGLIA, M. Coping, pain severity, interference, and disability: the potential mediating and moderating roles of race and education. Journal of Pain, n. 7, p. 459-68, 2006.

COONS, S; SHAW, J. Generic adult health status measures. In: HAYERS, P.; HAYS, R. Assessing quality of life in clinical trials. Oxford University Press, 2005.

COOPER, L.; GONZALES, J.; GALLO, J.; ROST, K.; MEREDITH, L.; RUBENSTEIN, L.; WANG, N.; FORD, D. The acceptability of treatment for depression among AfricanAmerican, Hispanic, and white primary care patients. Medical Care, n. 41, p. 479-89, 2003.

DEPARTMENT OF HEALTH AND HUMAN SERVICES - DHHS. Mental health: culture, race, and ethnicity - A Supplement to Mental Health: A Report of the Surgeon General. Rockville, MD: Department of Health and Human Services, Substance Abuse and Mental Health Services Administration, Center for Mental Health Services, 2001.

EDWARDS, C.; FILLINGIM, R.; KEEFE, F. Race, ethnicity and pain. Pain, n. 94, p. 133-7, 2001.
EDWARDS, R.; DOLEYS, D.; FILLINGIM, R.; LOWERY, D. Ethnic differences in pain tolerance: clinical implications in a chronic pain population. Psychosom Medicine, n. 63, p. 316-23, 2001.

ELLIS, C. Does race/ethnicity really matter in adult neurogenics? American Journal of Speech Language Pathology, 2009.

FAYERS, P.; MACHIN, D. Quality of life. Second Edition. West Sussex: John Wiley \& Sons, 2007.

FEENY, D.; FURLONG, W.; TORRANCE, G.; GOLDSMITH, C.; ZHU, Z.; DEPAUW, S.; DENTON, M.; BOYLE, M. Multiattribute and single-attribute utility functions for the health utilities index mark 3 system. Medical Care, n. 40, p. 113-28, 2002.

FERRARO, K. Are black older adults healthpessimistic? J. Health Soc. Behav., n. 34, p. 201-14, 1993.

FRYBACK, D.; DUNHAM, N.; PALTA, M.; HANMER, J.; BUECHNER, J.; CHEREPANOV, D; HERRINGTON, S.; HAYS, R.; KAPLAN, R.; GANIATS, T.; FEENY, D.; KIND, P. US norms for six generic health-related qualityof-life indexes from the national health measurement study. Medical Care, n. 45, p. 1.162-70, 2007.

FRYBACK, D.; PALTA, M.; CHEREPANOV, D; BOLT, D.; KIM, J. Cross-walks among five self-reported summary health utility indexes: progress and prospects. Society for Medical Decision Making Conference Proceedings, 2007.

GASKIN, D.; FRICK, K. Race and ethnic disparities in valuing health. Medical Decision Making, n. 28, p. 12-20, 2008.

GIVENS, J.; KATZ, I.; BELLAMY, S.; HOLMES, W. Stigma and the acceptability of depression treatments among african americans and whites. Journal Gen. Intern. Med., n. 22, p. 1.292-7, 2007.

GOLD, M.; STEVENSON, D.; FRYBACK, D. HALYS and QALYS and DALYS, Oh My: similarities and differences in summary measures of population Health. Annu Rev. Public Health, n. 23, p. 115-34, 2002. 
GONZÁLEZ, H.; CROGHAN, T.; WEST, B.; WILLIAMS, D.; NESSE, R.; TARRAF, W.; TAYLOR, R.; HINTON, L.; NEIGHBORS, H.; JACKSON, J. Antidepressant use in black and white populations in the United States. Psychiatr Serv., n. 59, p. 1.131-8, 2008.

GREEN, C.; ANDERSON, K.; BAKER, T.; CAMPBELL, L.; DECKER, S.; FILLINGIM, R.; KALAUOKALANI, D.; KALOUKALANI, D.; LASCH, K.; MYERS, C.; TAIT, R.; TODD, K.; VALLERAND, $A$. The unequal burden of pain: confronting racial and ethnic disparities in pain. Pain Med., n. 4, p. 277-94, 2003.

HAYS, R.; HAHN, H.; MARSHALL, G. Use of the SF-36 and other health-related quality of life measures to assess persons with disabilities. Arch Phys Med. Rehabil, n. 83, S4-9, 2002.

HEINS, J.; HEINS, A.; GRAMMAS, M.; COSTELLO, M.; HUANG, K.; MISHRA, $S$. Disparities in analgesia and opioid prescribing practices for patients with musculoskeletal pain in the emergency department. Journal Emerg Nurs, n. 32, p. 219-24, 2006.

IBURG, K.; SALOMON, J.; TANDON, A.; MURRAY, C. Cross-population comparability of self-reported and physician-assessed mobility levels: evidence from the Third National Health and Nutrition Examination Survey. In: WORLD HEALTH ORGANIZATION. Global Programme on Evidence for Health Policy, 17, 2001.

IEZZONI, L.; MCCARTHY, E.; DAVIS, R.; SIEBENS, H. Mobility difficulties are not only a problem of old age. J. Gen. Intern. Med., n. 16, p. 235-43, 2001.

KESSLER, R.; NEIGHBORS, H. A new perspective on the relationships among race, social class, and psychological distress. J. Health Soc. Behav., n. 27, p. 107-15, 1986.

KESSLER, R.; MCGONAGLE, K.; ZHAO, S.; NELSON, C.; HUGHES, M.; ESHLEMAN, S.; WITTCHEN, H.; KENDLER, K. Lifetime and 12-month prevalence of DSM-III-R psychiatric disorders in the United States. Results from the National Comorbidity Survey. Archives of General Psychiatry, n. 51, p. 8-19, 1994.
KESSLER, R.; NELSON, C.; MCGONAGLE, K.; LIU, J.; SWARTZ, M.; BLAZER, D. Comorbidity of DSM-III-R major depressive disorder in the general population: results from the US National Comorbidity Survey. Br. J. Psychiatry, Suppl., 17-30, 1996.

LAVEIST, T. A. Minority populations and health: an introduction to health disparities in the United States. San Francisco: JosseyBass, 2005.

LAZARUS, R.; FOLKMAN, S. Stress, appraisal, and coping. New York: Springer Pub. Company, 1984.

LEE, B.; CHABOYER, W.; WALLIS, M. Predictors of health-related quality of life 3 months after traumatic injury. J. Nurs Scholarsh, n. 40, p. 83-90, 2008.

MANLY, J.; JACOBS, D.; SANO, M.; BELL, K.; MERCHANT, C.; SMALL, S.; STERN, Y. Cognitive test performance among nondemented elderly African Americans and whites. Neurology, n. 50, p. 1.238-45, 1998.

MAYS, V.; COCHRAN, S.; BARNES, N. Race, race-based discrimination, and health outcomes among African Americans. Annu Rev. Psychol., n. 58, p. 201-25, 2007.

NAMPIAPARAMPIL, D.; NAMPIAPARAMPIL, J.; HARDEN, R. Pain and Prejudice. Pain Med., 2009.

NATIONAL CENTER FOR HEALTH STATISTICS, N. Health, United States, 2007. With Chartbook on Trends in the Health of Americans, 551. Hyattsville, MD, 2007.

NAUGHTON, M.; SHUMAKER, S. The case for domains of function in quality of life assessment. Quality of Life Research, n. 12, Suppl. 1, p. 73-80, 2003.

NG, B.; DIMSDALE, J.; ROLLNIK, J.; SHAPIRO, $\mathrm{H}$. The effect of ethnicity on prescriptions for patient-controlled analgesia for post-operative pain. Pain, n. 66, p. 9-12, 1996.

NG, B.; DIMSDALE, J.; SHRAGG, G.; DEUTSCH, R. Ethnic differences in analgesic consumption for postoperative pain. Psychosom Med., n. 58, p. 125-9, 1996. 
PASKETT, E.; ALFANO, C.; DAVIDSON, M.; ANDERSEN, B.; NAUGHTON, M.; SHERMAN, A.; MCDONALD, P.; HAYS, J. Breast cancer survivors' health-related quality of life: racial differences and comparisons with noncancer controls. Cancer, 2008.

PEREIRA, C. Some considerations about the use and applicability of preferencebased health-related quality of life measures to survivors of cancer in childhood and adolescence in developing countries. Revista Brasileira de Estudos de População, v. 26, n. 2, p. 295-303, 2009.

PESTA, B.; POZNANSKI, P. Black-White differences on IQ and grades: the mediating role of elementary cognitive tasks. Intelligence, n. 36, p. 323-329, 2008.

PRATT, S.; KULLER, L.; TALBOTT, E.; MCHUGH-PEMU, K.; BUHARI, A.; XU, X. Prevalence of hearing loss in black and white elders: results of the cardiovascular health study. J. Speech Lang Hear Res, 2009.

ROTH, R.; GEISSER, M. Educational achievement and chronic pain disability: mediating role of pain-related cognitions. Clin. J. Pain., n. 18, p. 286-96.

SCHULZ, A.; MULLINGS, L. Gender, race, class, and health: intersectional approaches. San Francisco, CA: Jossey-Bass, 2006.

SELIM, A.; FINCKE, G.; REN, X.; DEYO, R.; LEE, A.; SKINNER, K.; KAZIS, L. Racial differences in the use of lumbar spine radiographs: results from the veterans health study. Spine, n. 26, p. 1.364-9, 2001.

SHAW, J.; JOHNSON, J.; CHEN, S.; LEVIN, J.; COONS, S. Racial/ethnic differences in preferences for the EQ-5D health states: results from the U.S. valuation study. Journal of Clinical Epidemiology, n. 60, p. 479-90, 2007.

SHELINE, Y.; BARCH, D.; GARCIA, K.; GERSING, K.; PIEPER, C.; WELSHBOHMER, K.; STEFFENS, D.; DORAISWAMY, P. Cognitive function in late life depression: relationships to depression severity, cerebrovascular risk factors and processing speed. Biol. Psychiatry, n. 60, p. 58-65, 2006.
SIMPSON, S.; KRISHNAN, L.; KUNIK, M.; RUIZ, P. Racial disparities in diagnosis and treatment of depression: a literature review. Psychiatr Q, n. 78, p. 3-14, 2007.

SKARUPSKI, K.; DE LEON, C.; BIENIAS, J.; SCHERR, P.; ZACK, M.; MORIARTY, D.; EVANS, D. Black-white differences in health-related quality of life among older adults. Quality of Life Research, n. 16, p. 287-96, 2007.

SPENCER, S.; ALBERT, S.; BEAR-LEHMAN, J.; BURKHARDT, A. Relevance of race and ethnicity for self-reported functional limitation. J. Am. Geriatr. Soc., n. 56, p. 553-7, 2008.

SPENCER, S.; SCHULZ, R.; ROOKS, R.; ALBERT, S.; THORPE, R.; BRENES, G.; HARRIS, T.; KOSTER, A.; SATTERFIELD, S.; AYONAYON, H.; NEWMAN, A. Racial differences in self-rated health at similar levels of physical functioning: an examination of health pessimism in the health, aging, and body composition study. J. Gerontol. B Psychol. Sci. Soc. Sci., n. 64, p. 87-94, 2009.

STERNBERG, R.; GRIGORENKO, E.; KIDD, $\mathrm{K}$. Intelligence, race, and genetics. Am. Psychol., n. 60, p. 46-59, 2005.

THEIS, K.; MURPHY, L.; HOOTMAN, J.; HELMICK, C.; YELIN, E. Prevalence and correlates of arthritis-attributable work limitation in the US population among persons ages 18-64: 2002 National Health Interview Survey Data. Arthritis Rheum, n. 57, p. 355-63, 2007.

THORPE, R.; WEISS, C.; XUE, Q.; FRIED, L. Transitions among disability levels or death in African American and white older women. J. Gerontol. A Biol. Sci. Med. Sci., n. 64, 670-4, 2009.

TORRANCE, G.; FEENY, D.; FURLONG, W.; BARR, R.; ZHANG, Y.; WANG, Q. Multiattribute utility function for a comprehensive health status classification system. Health Utilities Index Mark 2. Medical Care, n. 34, p. 70222, 1996.

UNRUH, M.; BUYSSE, D.; DEW, M.; EVANS, I.; WU, A.; FINK, N.; POWE, N.; MEYER, K. Sleep quality and its correlates in the first 
year of dialysis. Clin. J. Am. Soc. Nephrol. n. 1, p. 802-10, 2006.

WARE, J.; SHERBOURNE, C. The MOS 36-item short-form health survey (SF-36). I. Conceptual framework and item selection. Medical Care, n. 30, p. 473-83, 1992.

WILLIAMS, D. Race in the health of America: problems, issues, and directions. Use of race and ethnicity in public health surveillance. Summary of the CDC/ATSDR Workshop. MMWR 1993; 42 (n. RR-10). Atlanta: CDC, 1993.

WILLIAMS, D.; YAN, Y.; JACKSON, J.; ANDERSON, N. Racial differences in physical and mental health: socio-economic status, stress and discrimination. Journal of Health Psychology, n. 2, p. 335-351, 1997.

WILLIAMS, D.; MOHAMMED, S. Discrimination and racial disparities in health: evidence and needed research. Journal of Behavioral Medicine, n. 32, p. 20-47, 2009.

WOLINSKY, F. The sociology of health: principles, practitioners, and issues. Belmont, California: Wadsworth Publishing Company, 1988.

\section{Resumo}

Domínios de saúde e raça nas medidas genéricas de qualidade de vida associada à saúde na literatura dos Estados Unidos

A literatura sobre raça nos Estados Unidos está repleta de estudos que documentam diferenças na saúde entre negros e brancos. Entretanto, a maioria dos trabalhos que exploram a relação entre raça e saúde utiliza medidas com saúde autorrelatada, mortalidade e morbidade, mas poucos empregam medidas de qualidade de vida relacionada à saúde e seus domínios específicos. Este artigo revisa a literatura sobre raça e qualidade de vida relacionada à saúde, especificamente examinando os domínios que constituem as principais medidas baseadas na teoria da utilidade: saúde física; saúde mental; dor e desconforto; cognição; domínios neurológicos; destreza; locomoção; vitalidade; e funcionamento social. Conduziu-se uma revisão da literatura usando as palavras-chave raça e o domínio da qualidade de vida de interesse nos Estados Unidos. Foram consultadas as bases de dados Medline/Pubmed, Web of Science e o portal Google Scholar. A maioria dos estudos sobre diversos domínios das medidas de qualidade de vida investigados sugere que negros têm pior qualidade de vida do que brancos nos Estados Unidos. A revisão salienta a escassez de estudos que exploram a relação entre raça e alguns domínios, como, por exemplo, funcionamento social, destreza, vitalidade e domínios de escopo neurológico, e, portanto, mostra a necessidade de que futuros estudos examinem a relação entre raça e estes domínios.

Palavras-chave: Raça. Qualidade de vida. EQ-5D. SF-6D. HUI2. HUI3. QWB domínios de saúde.

\section{Resumen}

Dominios de salud y raza en las medidas genéricas de calidad de vida, asociada a la salud, en la literatura de los Estados Unidos

La literatura sobre raza en los Estados Unidos está repleta de estudios que documentan diferencias en la salud entre negros y blancos. No obstante, la mayoría de los trabajos que explotan la relación entre raza y salud utiliza medidas con salud autorrelatada, mortalidad y morbilidad, pero pocos emplean medidas de calidad de vida relacionada con la salud y sus dominios específicos. Este artículo revisa la literatura sobre raza y calidad de vida relacionada 
con la salud, específicamente, examinando los dominios que constituyen las principales medidas basadas en la teoría de la utilidad: salud física; salud mental; dolor y molestias; cognición; dominios neurológicos; agilidad; locomoción; vitalidad; y funcionamiento social. Se realizó una revisión de la literatura usando las palabras-clave raza y el dominio de la calidad de vida de interés en los Estados Unidos. Se consultaron las bases de datos Medline/Pubmed, Web of Science y el portal Google Scholar. La mayoría de los estudios sobre diversos dominios de las medidas de calidad de vida investigados sugiere que los negros tienen peor calidad de vida que los blancos en los Estados Unidos. La revisión resalta la escasez de estudios que explotan la relación entre raza y algunos dominios, como, por ejemplo, funcionamiento social, agilidad, vitalidad y dominios de objetivo neurológico, y, por tanto, muestra la necesidad de que futuros estudios examinen la relación entre raza y estos dominios.

Palabras-clave: Raza. Calidad de vida. EQ-5D. SF-6D. HUI2. HUI3. QWB dominios de salud.

Recebido para publicação em 05/03/2010

Aceito para publicação em 07/07/2010 